\title{
Master Installation Design and Transformer Need Analysis in Faculty of Engineering Udayana University Denpasar
}

\author{
I G N Janardana ${ }^{1}$, W ArtaWijaya ${ }^{2}$, \\ ${ }^{1,2}$ Electrical Engineering Department \\ Faculty of Engineering Udayana University \\ Badung, Indonesian \\ janardana@unud.ac.id
}

\begin{abstract}
Faculty of Engineering, Udayana University, PB. Sudirman Denpasar has 5 building units (buildings A, B, C, D, AF). Currently the AF building is undergoing renovation and is planned to be on 4 floors. The entire building will be equipped with the installation of 2 elevator units. The construction of the two new buildings and the installation of the 2 elevator units caused new problems of electricity shortages, changes in safety settings, unbalanced loads, and changes in the size of the main cable and the needs of the transformer and its capacity. The AF building and building A are supplied from sources on the transformer which are joined with other faculties, while Buildings B, C, D and E are fed by one transformer No. 124303818 with a capacity of 160 kVA. The plan to build an Alumni Building does not yet have electricity. Based on the analysis of the design, the total amount of power needed in all buildings in the Sudirman Denpasar Faculty of Engineering is the result of the AF Building planning = 134,280 watts, the Alumni Building planning results (building area and building functions are considered equal $=134,280$ watts), so the total needs power to the two buildings $=271560$ Watt with a load deviation of $65 \%$, then $0.65 \times 271560 \mathrm{~W}=176514$ Watt. Then the total power requirement of the entire building is 259,340 watts. The measurement result of Cos 00.92 , then $\mathrm{P}$ $(\mathrm{kVA})=281,891,3043$ Ampere $=281,8913 \mathrm{kVA}$. So that the transformer needs that must be prepared by the Faculty of Engineering to meet the power requirements at the Faculty of Engineering, Udayana University Denpasar with 80\% transformer efficiency is a $350 \mathrm{kVA}$ transformer with a placement position around the Faculty of Engineering area.
\end{abstract}

Index Terms-Electric power, Electrical Installation, Transformer

\section{INTRODUCTION}

The Faculty of Engineering of Udayana University Denpasar has 5 building units (buildings A, B, C, D, AF). Currently the AF building is undergoing renovation and is planned to be on 4 floors. The entire building will be equipped with the installation of 2 elevator units. The construction of the two new buildings and the installation of the 2 elevator units caused new problems of electricity shortages, changes in safety settings, unbalanced loads, and changes in the size of the main cable and the needs of the transformer and its capacity. The AF building and building $A$ are supplied from sources on the transformer which are joined with other faculties, while Buildings $\mathrm{B}, \mathrm{C}, \mathrm{D}$ and $\mathrm{E}$ are fed by one transformer No. 124303818 with a capacity of $160 \mathrm{kVA}$. The Alumni Building plan does not yet have a electricity source

Corresponding author I G N Janardana - janardana@unud.ac.id
Based on these problems, the Faculty of Engineering of Udayana University is very urgent to review the need for electric power that is able to burden all the electrical system devices to avoid repeated blackouts and power quality is maintained. Then in this study an analysis of power requirements will be carried out due to the construction of the AF building and the alumni building of the Faculty of Engineering, Udayana University along with the addition of elevators.

\section{REVIEW OF LITERATURES}

\subsection{State of the Art}

1. Research on the analysis of electrical power requirements, room installation and load requirements calculation based on PUIL 2011, the design of air installations on, and the results obtained at the Kabakaba Estate villa with a total load requirement of $32,890.95 \mathrm{VA}$, with a grounding system using 3 plates [1] .

2. The study entitled "Electrical Installation System Planning in Renon Denpasar Bali Residential 
Development Project" analyzed the electrical power requirements, electrical installation planning and cooling systems [2].

3. Research on "Analysis of the Effect of Load and Harmonics Imbalance on Load in Neutral Wire and Transformer Power Loss". The results of the analysis found that the higher the level of load imbalance and harmonic distortion, the higher the level of neutral wiring, resulting in increased transformer losses [3].

4. Research on " Analysis of Grounding System As Building Equipment Security at Udayana University Denpasar " found results for the earthing system on the campus of the Faculty of Engineering Denpasar is still possible by installing one rod or 2 rods < L [4].

\subsection{Electric Power Systems}

An electric power system can be grouped into three main components, as follows [5], [6]:

1. Generating System

2. Transmission System

3. Distribution System

\subsection{Power Installation}

Equipment used in power installations is [6], [7]. :
a. Safety
b. Delivery
c. Contacts
d. Pushbutton
e. Contactor
f. Panel

\subsection{Basic Electric Power System Planning}

Several factors are influential and need to be considered in planning the distribution system in order to obtain optimal results, namely [5] :

1. Technical Factors

2. Economic Factors

3..Social Factors

\subsection{Analysis of Electric Power Needs}

2.5.1 Calculation of Indoor Lighting

Calculation of number of lights in a room [8] [9] [10] :

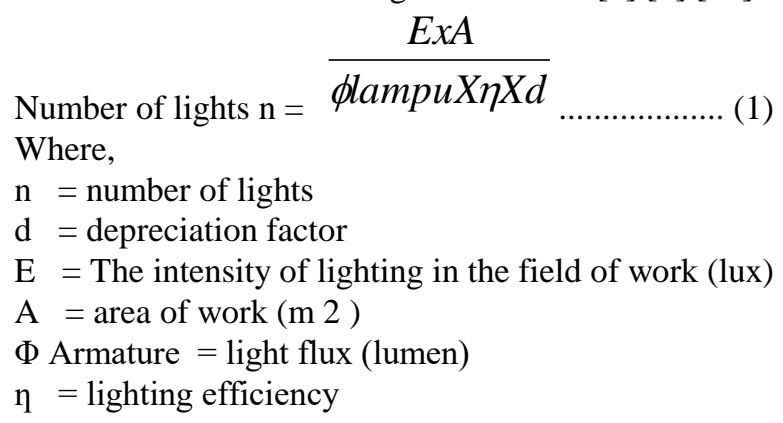

\section{5.2 Power requirements for Air Conditioner (AC)}

Increasing the efficiency of AC engine efficiency so that with $1 \mathrm{PK}$ power can be obtained by cooling up to 12,000 Btu / h AC Cooling Load / conditioning requirements in the room are influenced by [8] [9] : a. The number of calories caused by room fillers (devices and other supporting materials).

b. Volume and specifications of the room (walls, glass, wood, etc.).

Estimated cooling load requirements are as follows [8] :

1. Humans: $250-760 \mathrm{Btu} /$ person $($ male $=760 \mathrm{Btu} / \mathrm{h}$, female $=680 \mathrm{Btu} / \mathrm{h}$ )

2. Meeting rooms: 500 - $750 \mathrm{Btu} / \mathrm{m} 3$ (ideal).

3. Free space : $150-400 \mathrm{Btu} / \mathrm{m} 3$

\section{5.3 Power requirements for the elevator}

The existence of an elevator is a substitute for the function of the stairs in reaching each floor in a multi-storey building, therefore the existence of an elevator cannot be ruled out considering it can make energy and time efficient.

\subsubsection{Power requirements for equipment}

In its operation, a building will certainly be equipped with supporting equipment such as computers, LCD, Wi-Fi and others. Everything requires electrical power which is very necessary to be calculated so that electrical power remains available adequately.

\section{6 Earthing System}

Earthing system is a series / network starting from ground poles / electrodes, connecting conductors to ground terminals which function to channel excess current to earth, so that the equipment can avoid the effects of lightning and other foreign voltages [11] :

\section{7 Types of Electric Power Quality Problems}

Problems power quality such as symptoms of transition ( Transient), the symptoms of changes in variables (voltage, current, etc.) that occurred during the transition from soft operating conditions ( steady state ) to another state [12] .

\section{RESEARCH METHODS}

\subsection{Research Location}

The study was conducted at the Faculty of Engineering, Udayana University, Denpasar and the Electrical Installation Laboratory.

\subsection{Research Steps}

1. Collecting technical data on the existing electrical system's main installation.

2. Collecting data on the existing building loads: A, B, C, D, D and E.

3. Collecting data on AF building planning and Alumni buildings

4. Collecting technical data on elevator capacity

5. Measurement of earth resistance

6. Data collection for transformer installation.

7. Analysis of total load requirements and transformer capacity requirements .

\subsection{Data Analysis}


1. Analysis of the latest electrical power requirements in buildings A, BC, D, E.

2. Analysis of electrical power requirements in the $\mathrm{AF}$ building plan and alumni building.

3. Analysis of electrical power requirements and elevator capacity.

4. Analysis of power requirements for external lighting.

5. Analysis of total electric power requirements.

6. Analysis of transformer power requirements

7. Transformer placement analysis

\section{RESULTS AND DISCUSSION}

4.1 Electrical Systems at the Faculty of Engineering, Udayana University, Denpasar

Currently, it is planned to build an AF building and an alumni building with almost the same area. The entire load at the Denpasar Engineering Faculty is supplied from two transformers, namely at the secretariat building and building $\mathrm{A}$ is supplied from the source at the transformer which is incorporated with other Faculties, while Buildings B, C, D and $\mathrm{E}$ are supplied by one transformer No. 124303818 series with a capacity of $160 \mathrm{kVA}$.

4.2 Analysis of Electrical Power Requirements in AF Building Plans, Alumni Building and Lift Plans

The Faculty of Engineering of Udayana University is currently planning the construction of a building located on Jalan PB. Sudirman Denpasar. The building was built on an area of $384 \mathrm{~m} 2$ and planned to be built with 4 floors .

Based on data from the measurements of the building's existing electric power, the total real power needed in buildings $\mathrm{A}, \mathrm{B}, \mathrm{C}$ and the combined buildings $\mathrm{D}$ and $\mathrm{E}$ is 82,826 watts or $82,826 \mathrm{~kW}$. The measurement data is real data with the condition of all equipment operating. The results of the analysis of the new building plan using formula 1, formula 2 and the planned elevator specification data obtained the total number of loads in all buildings in the Sudirman Denpasar Faculty of Engineering are as follows:

- Building Planning AF $=134,280 \mathrm{~W}$

- Alumni Building Planning (building area and building functions are considered the same) $=134,280$ watts

The total power requirements of the two buildings $=271$ $560 \mathrm{~W}$. With a load deviation of $65 \%$, then; $0.65 \times 271560$ $\mathrm{W}=176514 \mathrm{~W}$

Then the total building power requirements from the measurement power data in buildings $\mathrm{A}, \mathrm{B}, \mathrm{C}, \mathrm{D}$ and $\mathrm{E}$ are added to the results of the 82.826 Watt planning power is 176,514 Watt $+82,826=259,340$ watts.

To determine the transformer capacity requirements that begin with a Cos pengukuran measurement of 0.92 are:

$$
\begin{aligned}
& \mathrm{P}(\mathrm{kVA})=259.340 / 0.92 \\
& =281,891,3043 \mathrm{VA} \\
& =281,8913 \mathrm{kVA}
\end{aligned}
$$

So that the transformer capacity needed is a transformer $281,8913+(20 \% \times 281,8913)=338.2695 \mathrm{kVA}$, with the transformer on the market is $350 \mathrm{kVA}$.

\subsubsection{Grounding System}

The Udayana University Faculty of Engineering Campus Denpasar with sandy clay texture. The earthing system installed at this time is the rod type. Based on the measurement results, the soil resistance value $=0.23 \mathrm{ohms}$, so that the ground $\rho$ is $28.89 \mathrm{Ohm}$-meters. The results of the analysis to get the earth resistance value $<3 \mathrm{Ohm}$, obtained type 2 (two) rods with $\mathrm{s}<\mathrm{L}$ obtained depth of 8 meters each with a distance between the electrodes of 2 meters obtained earth resistance value $2.4940 \mathrm{ohms}$.

\section{CONCLUSION AND RECOMMENDATION}

\subsection{Conclusion}

Based on the analysis of the design it was concluded that the total amount of power needed in all buildings in the Sudirman Denpasar Faculty of Engineering is the result of the AF Building planning $=134,280$ watts, the Alumni Building planning results (building area and building functions are considered equal $=134,280$ watts), so the total power requirements of the two buildings $=271560 \mathrm{Watt}$ with a load deviation of $65 \%$, then $0.65 \times 271560 \mathrm{~W}=176$ 514 Watt. Then the total power requirement of the entire building is 259,340 watts. The measurement result of Cos $\omega$ 0.92 , then $\mathrm{P}(\mathrm{kVA})=281,891,3043$ Ampere $=281,8913$ $\mathrm{kVA}$. So that the transformer needs that must be prepared by the Faculty of Engineering to meet the power requirements at the Faculty of Engineering, Udayana University Denpasar with $80 \%$ transformer efficiency is a $350 \mathrm{kVA}$ transformer with a placement position around the Faculty of Engineering area.

\subsection{Recommendation}

Based on the results of research to keep maintaining the quality of electric power after electric power is fulfilled, it can be recommended to conduct data collection of load data on a periodic basis for subsequent load growth.

\section{REFERENCES}

[1] Janardana, IGN. 2016. Sistem Pembumian Tipe Rod Sebagai Pengaman Peralatan Ruang Studio Teknik Arsitektur Gedung B Fakultas Teknik Universitas Udayana Jalan PB. Sudirman Denpasar. Denpasar : PS Teknik Elektro Unud.

[2] Hutaruk.TS.1987, Pengetanahan Netral dengan sistem Tenaga dan Pengetanahan Peralatan. Jakarta : Erlangga.

[3] Saini, M., dkk. 2010. Pengembangan Sistem Penangkal Petir Dan Pentanahan Elektroda Rod Dan Plat Pada Laboratorium Teknik Konversi Energi Politeknik Negeri Ujung Pandang. Academia.edu. https://www.academia.edu/8536126/

[4] Simamora, J., dkk. 2016. Pengaruh Penambahan Asam Sulfat(H2SO4) pada Bentonit untuk Penurunan Nilai 
Tahanan Pentanahan. Bandar Lampung : ELECTRICIAN-Jurnal Rekayasa dan Teknologi Elektro., Volume 10, No. 1.

[5] Zuhal. 1991.Teknik Tenaga Listrik Dan Elektronika Daya. Bandung : Gramedia.

[6] Sutikno, dkk. 1997. External \& Internal Grounding. Bandung :DIVLAT PT. Telkom.

[7] Widyaningsih, W.P. 2013. Perubahan Konfigurasi Elektroda Pentanahan Batang Tunggal Untuk Mereduksi Tahanan Pentanahan. EKSERGI Jurnal Teknik Energi., Vol : 9, No. 2 Mei 2013. 47-51.

[8] Syofian, A. 2013. Sistem Pentanahan Grid Pada Gardu Induk PLTU Teluk Sirih. Jurnal Momentum., Vol : 14, No. 1 Februari 2013.

[9] Nugroho, D. 2016. Konfigurasi Elektroda Batang Pada Sistem Pentanahan. Jurnal : Transistor., Vol : 6, No. 1. Juli 2006. 7-22.

[10]Rizal, Y., dkk, 2014. Analisis Kinerja Sistem Pentanahan PT. PLN (Persero) Gardu Induk $150 \mathrm{kV}$ Ngimbang-Lamongan Dengan Metode Finite Element Method (FEM). Surabaya : Jurnal Teknik POMITS 16.

[11] Yudha, D.O. dkk., 2015. Implementasi Sistem Pentanahan Grid Pada Tower Transmisi 150 kV( Aplikasi Pada Tower SUTT $150 \mathrm{kV}$ Antara Gardu Induk Indarung Dengan Gardu Induk Bungus).e jurnal.bunghatta.ac.id., Vol :5. No. 1. 2015.

[12] Persyaratan Umum Instalasi Listrik 2011(PUIL 2011). Amandemen 1. Jakarta : Badan Standardisasi Nasional. ICS : 13.260; 91.140.50. 